\title{
Gefitinib in treatment of metastatic non-small cell lung cancer (NSCLC) with mutated epidermal growth factor receptor (EGFR)
}

\author{
Charu Singh \\ From Society for Immunotherapy of Cancer 29th Annual Meeting \\ National Harbor, MD, USA. 6-9 November 2014
}

\begin{abstract}
Aim
To evaluate the efficacy, toxicity, overall survival and response of Gefitinib in previously untreated patients of metastatic NSCLC with EGFR mutation.
\end{abstract}

\section{Methods}

60 patients with metastatic, non-small-cell lung cancer and EGFR mutations who had not previously received chemotherapy were randomly assigned to receive Gefitinib $250 \mathrm{mg}$ orally daily or carboplatin -paclitaxel. The primary end point was progression-free survival; secondary end points included overall survival, response rate, and toxic effects.

\section{Results}

The progression free survival was significanly longer in Gefitinb group than in standard chemotherapy group. The Gefitinib group had significantly longer median progression free survival (10 months versus 5 months) as well as higher response rates (70\% versus $30 \%)$. The median overall survival was 30 months in Gefitinib group and 24 months in chemotherapy group. The most common adverse events in Gefitinib group were rash and elevated aminotransferase levels.

\section{Conclusions}

First-line Gefitinib for patients with advanced nonsmall-cell lung cancer who were selected on the basis of EGFR mutations improved progression-free survival, with acceptable toxicity, as compared with standard chemotherapy.

\section{Published: 6 November 2014}

S.M.S Medical College and Hospital, JAIPUR, India
doi:10.1186/2051-1426-2-S3-P187

Cite this article as: Singh: Gefitinib in treatment of metastatic non-small cell lung cancer (NSCLC) with mutated epidermal growth factor receptor (EGFR). Journal for ImmunoTherapy of Cancer 2014 2(Suppl 3): P187.
Submit your next manuscript to BioMed Central and take full advantage of:

- Convenient online submission

- Thorough peer review

- No space constraints or color figure charges

- Immediate publication on acceptance

- Inclusion in PubMed, CAS, Scopus and Google Scholar

- Research which is freely available for redistribution

Submit your manuscript at www.biomedcentral.com/submit
() Biomed Central 